\title{
Mythical Symbols in the Poetry of Ismail Kadare
}

\author{
Merxhan Avdyli \\ Faculty of Education, Public University "Kadri Zeka" Gjilan, Republic of Kosovo
}

Copyright@2019 by authors, all rights reserved. Authors agree that this article remains permanently open access under the terms of the Creative Commons Attribution License 4.0 International License

\begin{abstract}
Mythology, in the poetry of Kadare, is quite present. It is presented as a special theme, which reveals not only the poetic but also philosophical ideas of Kadare. As such, mythical topography in Kadare's poetry is not only presented in various forms, but also presented with numerous mythological figures, especially from ancient Greek mythology, and also from Albanian mythology. Being present in poetry of Kadare, mythical topics are always in the function of comparing with contemporarily, taking the examples of mythological figures and heroes, but their places, not rarely implied as influential or comparable elements: mythical heroes with personalities from contemporary; their actions with the events and actions of modernity, and the ancient places with today's countries, either as patriotic or enemy countries.
\end{abstract}

Keywords Kadare, Poetry, Topics, Myth, Troy, Laocoon, Hero, Figure, War, Fall, Love, Betrayal, Land, Mythology, Idea, Realization

\section{Introduction}

Mythology, in the poetry of Kadare, is quite present. It is presented as a special theme, which reveals the not only poetic but also philosophical ideas of Kadare. As such, the mythical theme in Kadare's poetry is not only presented in various forms, but it is also presented with numerous mythological figures, especially from ancient Greek mythology, but also from Albanian mythology. Being present in the poetry of Kadare, the mythical topicality is always in the function of comparing with contemporaryity, taking the examples from mythological figures and heroes, but also from their countries, not rarely implied as influential or comparable elements: mythical heroes with personalities from contemporary; their actions with the events and actions of modernity, and the ancient countries with today's places, either as patriotic topical or topical sites of enemy countries.

On this occasion it should be noted that Ismail Kadare is present in front of the Albanian public as well as before that non-Albanian one. Ismail Kadare's works have been translated into many different languages of the world. In general Kadare's literary works have been translated into 45 world languages. His poetic works have been translated less than his works in prose. Here too it must be said that his poetry does not have that reflection as his prose has. Even his poetry has been studied less, not only by foreign literary critics but also by literary Albanian critics. However, it must be claimed that his poetry has had an appreciable impact on Albanian poets, especially those of the second part of the twentieth century.

\section{Troy and Betrayal}

The Trojan War [1] is one of the greatest events of the ancient history of antiquity, which Kadare uses to create, in the majority of cases, historical parallelism, which it uses to create a new artistic reality and that are always in function, not only human and humanistic, but also historical and national awareness. Almost all the figures from antiquity, Kadare introduce them to the present. Thus, Troy prevails as topical, as a sign, as a motif, as a symbol and as a figure, in these segments of his poetry. Troy also comes out as a war, as a confrontation, as a resistance, as a fall, as a love, as a betrayal. With all its mythical heroes and antiherons, from whose deeds Kadare builds his poetry, respectively, the topical lyric. [2]

Troy, in the poetry of Kadare, is a sign that is often used, even used for the best poems, but poetry, such as "Troy", [3]" You were for me ", [4]" Eksorcizmi ", [5]" Laocoön " [6] and " Trojan Horse ". [7]

In Troy's poetry the basic idea of the betrayal, the author makes a recapitulation of history from the fall of Troy to this day, through reading history, attempting a considerable part of the people to stuck the horse and presenting millions of others, reciting Homer's verses as a "de profundis".[8] However, Kadare's poetic power [9] comes to the surface of the last and complete verse of poetry, which simultaneously represents the recapitulation and sublimation of her idea, in which the poet, using the personification, addresses the latter in the last verse through the embroidery, saying:

Push for centuries by putting 
This horse age will traverse

In his boat forever he will tremble

The terrible betrayal of Troy. [10]

\section{Troy and Love}

Being Troy and her war is an inexhaustible poetic motive, Kadare also uses it in love-motivated poetry, as is the poem "You were for me", which is one of the best poems of poems of love, with comparisons and metaphors quite hit. The collapse of Troy, which has motivated the artists of various profiles of all the historical epochs, from Homer and beyond to Kadare has been utilized in an original look, through an original comparison, where the invasion of a woman's love is compared with the invasion of Troy (as ironically, even the Trojan War itself was done because of the abduction of a woman!).

Meanwhile, the poet states:

You were for me as invincible as Troy

Troy that I could not overtake. [11]

Further, nonconclusion brings Platonic love, a love realized only in dreams, as in the verses:

Just in dreams, ah in dreams

To embrace the dense hair,

The more gas I felt in my pursuit

That all Greeks when Troy fell. [12]

\section{Laocoön and Comparison of Historical Epochs}

Poetry "Laocoön"[13] is one of Kadare's best poetry, anthology poetry, which based on the idea and the theme that it has, is the most typical representative of Kadare's poetry, which ancient figures use, whether to explain our newest story, whether to explain the different historical and political characters, making different comparisons and finding numerous connotations. He also uses Laocoön's figure in this same function. Being a great master of comparing historical and historical events, moments, events and various social phenomena, he thus connects indissoluble historical epochs, giving them different attributes and wearing them with hues different historical, and often political.

But Laocoön, in Kadare's poetry of the same name, has a different use from the essence of the mythological Laocoön's action, in which Kadare through him conveys historical messages, making different temporal and historical parallelisms, perpetuating the image heroic and tragic of Laocoön, who for over three thousand years is still carrying the mythological truth about his murder, which turns out to be a lie, since after three thousand years Laocoön declared that his killers were not his snakes and both his sons, but they were the trojans who had killed him.

In this way, it should be noted that poetry "Laocoön" is an almost monumental picture of the mythological figure of Laocoön, where Kadare with artistic means overthrows Homerian truth and the myth of the death of Laocoön and his two sons after failing in his efforts to persuade the trojans not to accept the aqeedah gift he had given as a gift of betrayal - the wooden horse. Although poetry is a historical-mythological reminiscence, the punishment of Laocoön and his two sons by the snakes, Kadare overturned, expressing his resurrected conclusion after three thousand years:

The snakes did not kill me, but the trojans killed me. [14]

A reversal of a historical and mythological "truth" that Kadare later develops, making Laocoön himself speak, three thousand years later, communicating with the new story, namely our present:

You know what happened to Troy.

Three thousand years in a row,

From museum to museum

I hamalli i sermons lie hold.

Three thousand years ... Still the fires of Troy

Like red hair I stick to the eye. [15]

\section{Three Mythical Symbols}

We said above that the mythical topic in Kadare's poetry is present with Troy that is through Troy with the war, with the fall and with her heroes, but also with a mythologically and historically renowned tree figure of Troy's Horse. Even Troy, and her heroes, in the poetry of Kadare, has become symbols, even in meaningful symbols, which reinforce the idea of his poetry and raise the literal and aesthetic value of his poetry. [16]

Using the mythological material that has to do with Troy and her heroes, Kadare has particular preoccupation. He cares about this preoccupation and explains it in his book "Studio Invitation".[17]

Zeus, Homer, Troy, Troy Horse, Laocoön, Rome are names and signs that in Kadare's poetry have been transformed into special symbols for certain phenomena.

But we will stop at treating three mythical symbols, from Kadare, which are not only more characteristic but that his poetry brings figurative novelty. Troy, Trojan Horse and Laocoön are three symbolic figures used by Kadare and which have been carved with a pronounced originality.

Troy, in the poetry of Kadare, is a double symbol: of conquest and non-conquest. While in "Troy" poetry, the symbol is about invasion, falling and treason, coming from a wooden horse, to another poem where Troy is used as a parallelism to conquer a woman's love, the symbol of Troy, already implies the difficulty of invasion, the impossibility of invasion, or non-conquest, as expressed in a Kadare case. [18]

Below we will look at the case when Troy, as a symbol, is used with various symbolic meanings, even in this case not of conquest, but of non-conquest. This symbol is 
present in the poem "You were for me", as in the verses:

You were unconvincing for me like Troy,

Troy that I could not overtake. [19]

\section{Expressive Forms of Fraud and Betrayal}

Troy's horse, in the poetry of Kadare, is used as a symbol of betrayal and deception. His presence in some of Kadare's poems proves his preoccupation with this well-known topic since ancient times and worked and elaborated for centuries. The universal theme of betrayal, among other things, uses Kadare in his poetry to create historical parallelisms of mythology with contemporarily, since betrayal, regardless of time, has the same consequences and as such is the overwhelming passion of human destiny over the centuries. There are some poems, which are the hallucinations of Troy's treachery, but there are three of them, which are perfectly accomplished as "Laocoön", "Troja" and "Trojan Horse".

Fraud and betrayal are expressed in these poems, in various forms eg. and poetry "Laocoön":

The wooden gift basket of the Greeks shows you

This horse in two groups divided trojans:

Accept it or throw it away. [20]

Meanwhile, in poetry "Troy", where we have the symbol of conquest and treachery, according to the author has been transferred and will be followed for centuries by people:

Push for centuries by putting

This horse of ages will go through;

In his boat forever he will tremble

The terrible betrayal, Troy! [21]

The same message is conveyed by the poem "Troy Horse", which treats betrayal as an element that has been carried over for centuries in society, while in this poem the author draws attention to his knock, which since ancient times is feeling in today's human society, the myth is coming to modernity. With the following verses, the author orders and calls for vigilance:

In the calm of the night, give ear,

Do not you hear that far a knockout?

From the depths of ancient myths to our modern cities

A horse is trotting

It's Trojan Horse. [22]

\section{Conclusions}

The Trojan War is one of the greatest events of the ancient history of antiquity, which Kadare exploits to create in most cases the historical parallels that they use to create a new artistic reality that is always in function, not only human and humanistic, but also historic and national. Almost all of the figures from antiquity, Kadare introduce them to the present. Troy prevails, as a topical, a sign, as a motif, as a symbol and as a figure, in these segments of his poetry. Troy also comes out as a war, as a confrontation, as a resistance, as a fall, as a love, as a betrayal. With all its mythical heroes and antiheroes, whose deeds Ismail Kadare builds his poetry, respectively, in this case the topical lyric.

\section{REFERENCES}

[1] For Troy's War is written in all world languages, world literature is filled with numerous examples of dealing with this war. Troy occupies a special place in today's Albanian poetry, Kadare is one of the ones who has most exalted in his poetry the Trojan War and her heroes.

[2] Topics of Kadare not only conclude with his lyric, which dominates mythical symbols, but it also extends with other symbols.

[3] Ismail Kadare, Përse mendohen këto male, (Why are these mountains), "Naim Frashëri”, Tiranë, 1964, p. 21.

[4] Ismail Kadare, Përse mendohen këto male, (Why are these mountains), "Naim Frashëri”, Tiranë, 1964, p. 30.

[5] Ismail Kadare, Ftesë në studio, poezi, shënime shënime (Invitation to the studio, poetry, notes), "Naim Frashëri", Tiranë, 1990, p. 47.

[6] Ismail Kadare, Koha, (Time), "Naim Frashëri”, Tiranë, 1976, p. 74 .

[7] Ismail Kadare, Motive me diell (Sunni motives), "Rilindja", Prishtinë, 1978, p. 76.

[8] De profundis - from the bottom, deeply. Constern prayer of repentance to Christians.

[9] The poetic power of Kadare's lyricism is witnessed and as such it is read and felt today in other world languages. His poems, as well as prose, have been translated into world languages such as English (translator Robert Elsie, David Bellos, John Hodgson Ani Kokobobo, Arshi Pipa); French (translator Michel Metais, Jusuf Vrioni, Ted Papavram, Eric Faye); Italian (translator Joyce Lussu Kudret Kokoshi); German (translator Hans-Joachim Lanksch, Romanian (translator Marius Dobresku), Chinese (translator Zheng Enbo, Gao Xing) Russian (translator Vasili Tjuhin).

[10] Ismail Kadare, Përse mendohen këto male, (Why are these mountains), "Naim Frashëri”, Tiranë, 1964, p. 21.

[11] Ismail Kadare, Përse mendohen këto male, (Why are these mountains), "Naim Frashëri”, Tiranë, 1964, p. 30.

[12] Ismail Kadare, Përse mendohen këto male, (Why are these mountains), "Naim Frashëri”, Tiranë, 1964, p. 30.

[13] From various scholars, the long poem "Laocoön" is considered a poem. Indeed this poetic work has the elements of a poem.

[14] Ismail Kadare, Koha, (Time), "Naim Frashëri”, Tiranë, 1976, p. 75 . 
[15] Ismail Kadare, Koha, (Time), "Naim Frashëri”, Tiranë, 1976, p. 77.

[16] Kadare's literary work is more prosaic than poetry has been studied by authors from various states who have published works and studies for her in their native languages: Eric Faye and Jean-Paul Champseix (French), Piet de Moor (Dutch), Peter Morgan (English), Joice Lussu (Italian), Jose Carlos Rodrigo Breto (Spanish) etc.

[17] Ismail Kadare, Koha, (Time), "Naim Frashëri”, Tiranë, 1976, p. 297.

[18] Ismail Kadare, Koha, (Time), "Naim Frashëri”, Tiranë, 1976, p. 297.

[19] Ismail Kadare, Përse mendohen këto male, (Why are these mountains), "Naim Frashëri”, Tiranë, 1964, p. 30.

[20] Ismail Kadare, Koha, (Time), "Naim Frashëri”, Tiranë, 1976, p. 75.

[21] Ismail Kadare, Përse mendohen këto male, (Why are these mountains), "Naim Frashëri", Tiranë, 1964, p. 21.

[22] Ismail Kadare, Motive me diell, "Rilindja" (Sunni motives), Prishtinë, 1978, p. 76.

[23] Frymëzimet djaloshare (The boy's inspiration), Ndërmarrja Shtetërore e Botimeve, Tiranë, 1954.

[24] Ëndërrimet... (Dreaming...), Ndërmarrja Shtetërore e Botimeve, Tiranë, 1957.

[25] Princesha Argjiro (Princess Argjiro), Ndërmarrja Shtetërore e Botimeve, Tiranë, 1958.

[26] Shekulli im (My century), "Naim Frashëri”, Tiranë, 1961.

[27] Përse mendohen këto male (Why are these mountains), "Naim Frashëri", Tiranë, 1964.

[28] Vjersha dhe poema të zgjedhura, (Selected poems) "Naim Frashëri”, Tiranë, 1966.

[29] Gurgdhendësit, poemë (Masons, poem), "Naim Frashëri”, Tiranë, 1967.

[30] Motive me diell (Sunni motives), "Naim Frashëri", Tiranë, 1968.

[31] Poema të zgjedhura për fëmijë (Selected poems for children), "Naim Frashëri", Tiranë, 1975.

[32] Koha (Time), "Naim Frashëri”, Tiranë, 1976.

[33] Poezi (Poetry) “Naim Frashëri”, Tiranë, 1976.

[34] Në muzeun e armëve, poemë (In the Weapons Museum, poem), "Naim Frashëri”, Tiranë, 1978.

[35] Motive me diell (Sunni motives), "Rilindja", Prishtinë, 1978

[36] Buzëqeshje mbi botë (Smile on the world), "Rilindja", Prishtinë, 1980.

[37] Poezi (Poetry), Shtëpia Botuese e Librit Shkollor, Tiranë, 1985.

[38] Ftesë në studio, poezi, shënime shënime (Invitation to the studio, poetry, notes), "Naim Frashëri”, Tiranë, 1990.

[39] Ca pika shiu ranë mbi qelq (40 poezi të zgjedhura) The rain drops on the glass (40 selected poems), "Onufri", Tiranë, 2006.

[40] Pa formë është qielli (100 poezi dhe poema të zgjedhura) Without form is heaven (100 selected poems), "Onufri", Tiranë, 2006.

[41] Kristal (60 poezitë zgjedhura) Crystals (60 selected poems), "Onufri", Tiranë, 2007.

[42] Vepra, vëllimi 7 (Works, volume 7), “Onufri”, Tiranë, 2008.

[43] Aliu, Ali, Kërkime (Pioneering) "Rilindja”, Prishtinë, 1980.

[44] Avdyli, Merxhan, Sprova zbuluese të poetikës (The exploration of poetry), Brezi 81, Prishtinë, 2005.

[45] Bart, Rolan, Književnost, mitologija, semiologija (Literature, mythology, semiology), Beograd, 1971.

[46] Beker, Miroslav, Suvremene književne teorije (Contemporary literary theories), SNL, Zagreb 1986.

[47] Çapriqi, Basri, Paradigma kadareane (The paradigm of kadarean), Onufri, Tiranë, 2006.

[48] Çaushi, Tefik, Universi letrar i Kadaresë (Kadare's literary universe), "Evropa", Tiranë, 1993.

[49] Friedrich, Hugo Struktura moderne lirike (Modern lyrical structure), Stvarnost, Zagreb, 1969.

[50] Kyçyku, Bashkim, Kadare në gjuhët e botës (Kadare in the languages of the world), "Onufri”, Tiranë, 2000.

[51] Metais, Michel, Ismail Kadare et la nouvelle poezie albanaise (Ismail Kadare and the new Albanian poetry), Paris, P.J. Oswald, 1973.

[52] Uçi, Alfred, Grotesku kadarean (Grotesque kadarean), "Onufri”, Tiranë, 1999.

[53] Zamputi, Injac, Ekskursion në dy vepra të Kadaresë (Excursion to two Kadare books), Tiranë, 1993.

[54] Zheji, Gjergj, Bazat e vargëzimit shqiptar, "Rilindja", Prishtinë, 1990.

[55] Zhenet, Zherar, Figurat (Figures), "Rilindja", Prishtinë, 1985.

[56] Faye, Eric, Ismail Kadare: Promethe, porte-feu (Paris, 1991)

[57] De Moor, Piet, Een masker voor de macht. Ismail Kadare, schrijver in de dictatuur (A mask for power. Ismail Kadare, writer in the dictatorship), Amsterdam, 1996.

[58] Morgan, Peter - Kadare: Writer and dictatorship, 1957-1990, London, 2010.

[59] Breto, José Carlos Rodrigo - Ismaíl Kadaré y la Gran Estratagema: reflejos literarios del totalitarismo (Ismaíl Kadare and the Great Stratagem: Literary Reflections of Totalitarianism), Madrid, 2015.

[60] Elsie, Robert, Albanian Literature: A Short History, London: I.B.Taurus, 2005. 